\title{
EQUITY RISK PREMIUM PADA INDUSTRI PERBANKAN
}

\author{
Yunus Harjito \\ Universitas Setia Budi Surakarta \\ yunus.harjito@gmail.com \\ Dian Indriana Hapsari \\ Universitas Setia Budi Surakarta \\ canza_zone@yahoo.com
}

\begin{abstract}
This study aims to examine the factors that influence the equity risk premium in the banking industry are listed on the Indonesia Stock Exchange. The samples used were 23 banking industry for 2010-2014. Five variables proposed that auditor tenure, earnings quality, leverage, beta, and earnings per share to detect whether there is an influence on the equity risk premium. Equity risk premium is desired reward investors to generate income is not fixed in relation to the equity share hers. So far the equity risk premium is often described as the most important value in finance and investment. Analysis of the data used in this research is multiple linear regression with the hope to obtain a comprehensive picture of the influence of variables auditor tenure, earnings quality, leverage, beta, and earning per share of the equity risk premium by using SPSS version 21 for Windows. The results showed that the auditor tenure, earnings quality, and earnings per share significantly affect the equity risk premium. But two other variables (leverage and beta) proved no effect on the equity risk premium.
\end{abstract}

Keywords: Equity risk premium, auditor tenure, quality of earnings, leverage, beta, earning per share.

\section{A. Pendahuluan}

Hukum investasi menyatakan bahwa semakin tinggi return yang ditawarkan semakin tinggi pula risiko (risk) yang harus ditanggung investor. Risk and return adalah kondisi yang 
dialami oleh investor dalam keputusan investasi, baik kerugian maupun keuntungan dalam suatu periode akuntansi. Bagi investor, kondisi demikian merupakan hal yang biasa, karena investor beranggapan bahwa kesediaan untuk menanggung risiko besar akan terbayar dengan return yang lebih besar dibandingkan risiko tersebut. Pandangan lain menyatakan bahwa kesediaan untuk menanggung risiko investasi saham harus dibayar dengan tambahan return yang akan diperoleh investor dari investasi tersebut. Tambahan return tersebut sering dikenal dengan istilah Equity Risk Premium.

Equity risk premium merupakan imbalan yang diinginkan investor untuk menghasilkan pendapatan tidak tetap sehubungan dengan saham ekuitas miliki. Equity risk premium diukur sebagai return yang diharapkan pemegang saham melebihi rata-rata aset bebas risiko (Annin dan Falaschetti, 1998). Selain itu, Martin dan Lilo (2003) menjelaskan bahwa equity risk premium sering diuraikan sebagai nilai yang paling penting dalam keuangan dan investasi. Pada keputusan penganggaran modal ditingkat perusahaan, equity risk premium merupakan masukan dalam biaya modal, tingkat diskonto yang digunakan untuk menghitung net present value investasi. Equity risk premium juga merupakan masukan yang penting dalam menghitung biaya modal yang memiliki peran untuk menentukan harga maksimum barang dan jasa dari utilitas Pemerintah.

Sejauh ini, terdapat beberapa faktor yang diduga dapat mempengaruhi tinggi rendahnya tingkat equity risk premium diantaranya adalah AuditorTenure (Leuz dan Verecchia, 2005; Mansiet al., 2004); Kualitas Laba, Leverage, Beta (Saiful dan Erliana, 2010); earning per share(Boone, et al., 2008; Fama dan French, 1992) dan lain sebagainya. Guna menilai tingkat equity risk premium, perusahaan perbankan dapat menyajikan hasil yang lebih baik, karena perbankan sarat dengan berbagai regulasi. Sebagai suatu lembaga intermediary/perantara keuangan yang menghubungkan pihak yang kelebihan dan pihak yang memerlukan dana, maka risiko yang harus dihadapi oleh bank sangat besar. Ketidakmampuan untuk menjaga image (kualitas) akan sangat berpengaruh terhadap likuiditas bank (Rahmawati et al., 2006). 
Saiful dan Erliana (2010) menunjukkan bahwa auditor tenure tidak berpengaruh terhadap equity risk premium. Berbeda dengan hasil penelitian Booneet al. (2008) yang menunjukan bahwa masa penugasan auditor berhubungan negatif secara signifikan, menandakan bahwa apabila masa penugasan auditor bertambah maka equity risk premium akan menurun. Diaz (2009) menganalisis reaksi pasar terhadap pengumuman penggantian kantor akuntan publik menemukan bahwa perusahaan yang melakukan penggantian auditor mengalami abnormal return yang negatif.

Francis et al. (2004); Boone et al. (2008) menjelaskan bahwa semakin tinggi kualitas laba perusahaan maka semakin rendah equity risk premium perusahaan tersebut. Hasil ini konsisten dengan Leuz dan Verrecchia (2005) yang menyatakan bahwa kualitas laba tinggi akan meningkatkan aliran kas dan menurunkan biaya modal sehingga berdampak pada menurunnya equity risk premium perusahaan. Berbeda dengan hasil penelitian Saiful dan Erliana (2010) yang menyatakan tidak menemukan pengaruh kualitas laba terhadap equity risk premium.

Bhandari (1988) menyatakan bahwa leverage memiliki hubungan positif terhadap tingkat return yang diharapkan, saham dengan nilai rasio leverage yang tinggi memiliki tingkat return yang relatif tinggi terhadap beta pasarnya. Hasil penelitian ini konsisten dengan penelitian Gebhart, et al. (2000) dan Boone et, al. (2008) tetapi bertentangan dengan hasil penelitian Kurniawan (2013) yang menyatakan aset yang dibiayai oleh utang (pengukuran laverage) tidak memberikan pengaruh terhadap risiko dalam melakukan investasi pada saham. Booneet al. (2008) menemukan bahwa beta berpengaruh positif terhadap equity risk premium. Hasil tersebut tidak konsisten dengan hasil penelitian Situmorang (2015) yang menyatakan sebaliknya

Aloysius (2004) dan Chen (2006) menunjukkan bahwa earning per share merupakan variabel yang positif dan signifikan dalam menerangkan perubahan return saham dan equity risk premium. Semakin tinggi earning per share maka semakin meningkatkan equity risk premium.Hasil tersebut berbeda dengan penelitian Al-hayat(2014) yang menyatakan 
bahwaearning per share tidak berpengaruh terhadap return saham.

Hasil penelitian ini secara praktis diharapkan dapat menjadi acuan atau referensi bagi pihak perusahaan (khususnya perbankan) untuk meningkatkan kinerja perusahaan dalam rangka untuk meningkatkan return saham. Sedangkan bagi investor dapat digunakan sebagai pertimbangan dalam keputusan investasi. Secara teoritis diharapkan penelitian ini dapat menambah pengetahuan dan wawasan terkait dengan equity risk premium di Indonesia, khususnya untuk industri perbankan. Penelitian ini juga diharapkan dapat digunakan sebagai acuan penelitian selanjutnya pada bidang sejenis.

\section{Teori Portofolio}

Teori portofolio (portofolio theory) menyatakan bahwa risiko dan pengembalian harus dipertimbangkan dengan asumsi tersedia kerangka formal untuk mengukur keduanya dalam pembentukkan portofolio. Dalam bentuk dasar, teori portofolio dimulai dengan asumsi bahwa tingkat pengembalian atas efek dimasa depan dapat diestimasi dan kemudian menentukan risiko dengan variasi distribusi pengembalian. Berdasar asumsi tertentu, teori portofolio menghasilkan hubungan linear antara risiko dan pengembalian (Markowitz, 1952).

Teori portofolio berkaitan dengan estimasi investor tehadap ekspektasi risiko dan return dalam membentuk portofolio investasi. Husnan (2003) menjelaskan bahwa portofolio berarti sekumpulan investasi. Tahap ini menyangkut identifikasi sekuritas mana yang akan dipilih dan berapa proporsi dana yang akan ditanamkan pada masing-masing sekuritas tersebut. Diversifikasi dimaksudkan untuk mengurangi risiko yang ditanggung. Pemilihan sekuritas ini dipengaruhi oleh preferensi risiko pola kebutuhan kas, status pajak, dan sebagainya. Besar risiko dapat dikurangi dengan menambah jumlah jenis aset ke dalam portofolio dan tingkat expected return dapat naik jika investasinya terdapat perbedaan pergerakan harga dari aset-aset yang dikombinasi tersebut (Markowitz, 1952). 


\section{Teori Agensi (Agency Theory)}

Jensen and Meckling (1976) mendefinisikan bahwa hubungan keagenan sebagai suatu kontrak, dimana satu orang atau lebih (prinsipal) meminta pihak lainnya (agen) untuk melaksanakan sejumlah pekerjaan atas nama prinsipal, yang melibatkan pendelegasian beberapa wewenang pembuatan keputusan kepada agen. Jika kedua pihak yang terlibat dalam kontrak tersebut berusaha untuk memaksimalkan utilitas, maka ada kemungkinan bahwa agen tidak akan selalu bertindak untuk kepentingan terbaik prinsipal. Dengan tujuan memotivasi agen, maka prinsipal merancang kontrak sedemikan rupa sehingga mampu mengakomodasi kepentingan pihak-pihak yang terlibat dalam kontrak keagenan.

Teori agensi mengasumsikan bahwa semua individu bertindak atas kepentingan sendiri. Pemilik perusahaan sebagai principal diasumsikan hanya tertarik pada hasil keuangan atau nilai investasi yang meningkat. Sedangkan manager sebagai agent diasumsikan menerima kepuasan berupa kompensasi keuangan dan terpenuhinya syarat-syarat yang menyertai dalam hubungan tersebut. Perbedaan kepentingan tersebut membutuhkan adanya pihak lain yang independen guna memediasi hubungan agent dan principal agar silang kepentingan tidak mengganggu kelangsungan hidup entitas. Pihak yang memoderasi hubungan tersebut adalah akuntan publik (auditor).

\section{Equity Risk Premium}

Equity Risk Premium merupakan perbedaan antara return yang diharapkan pada saham biasa dan return pada sekuritas pemerintah (Martin dan Lilo, 2003). Annin dan Falaschetti (1998) mendefinisikan sebagai imbalan yang diinginkan investor untuk menghasilkan pendapatan tidak tetap sehubungan dengan ekuitas yang dimiliki. Equity risk premium mencerminkan harga dari risiko yang diambil dan merupakan komponen utama atas return yang diharapkan yang dituntut pada investasi berisiko. Return yang diharapkan merupakan faktor penentu dari biaya modal serta input yang penting dalam analisis keuangan dan penilaian perusahaan (Damodaran, 2009). 
Saiful dan Erliana, (2010) menguraikan bahwa terdapat dua cara umum untuk memperkirakan equity risk premium, yaitu menggunakan data historis dan perkiraan atau proyeksi pasar. Jika menggunakan data historis, asumsinya bahwa apa yang terjadi di masa lalu mencerminkan apa yang mungkin terjadi di masa depan. Jika menggunakan proyeksi pasar, asumsinya bahwa untuk memproyeksikan equity risk premium dapat dilakukan melalui survey atau beberapa model proyeksi lain. Sebagian besar model equity risk premium menggunakan data historis dan mengasumsikan bahwa beberapa periode masa lalu menyediakan indikasi terbaik dari apa yang akan terjadi di masa depan. Jadi, model equity risk premium yang menggunakan proyeksi masa depan sebagai dasar tidak berfungsi dengan baik. Equity risk premium dihitung dengan menggunakan CAPM (Saiful dan Erliana, 2010) yang diperkenalkan oleh Annin dan Falaschetti (1998).

Equity Risk Premium $=\frac{R i-R f}{\beta}$

$\mathrm{R} i=$ tingkat return perusahaan.

$\mathrm{Rf}=$ tingkat return aset bebas risiko.

$\beta=$ beta saham.

\section{Auditor Tenure}

Auditor Tenure merupakan masa perikatan (keterlibatan) antara Kantor Akuntan Publik (KAP) dan klien terkait jasa audit yang disepakati. Isu mengenai auditor tenure biasanya dikaitkan dengan pengaruhnya terhadap independensi auditor. Pemilik perusahaan membutuhkan auditor untuk memverifikasi informasi yang diberikan manajemen kepada pihak perusahaan. Dalam pengaturan portofolio, perusahaan audit menyesuaikan portofolio klien untuk menerima klien berisiko atau mentolerir klien relatif berisiko dalam pelaporan keuangan (misalnya, manipulasi laba) berdasarkan periode diperpanjang dalam perubahan kondisi ekonomi dan institusional.

Al-Thuneibat, et al. (2011) menyatakan bahwa hubungan yang lama antara auditor dan klien berpotensi menciptakan kedekatan sehingga dapat menghalangi independensi auditor dan mengurangi kualitas audit. Booneet al. (2008) percaya bahwa hubungan yang panjang bisa menyebabkan auditor 
memiliki kecenderungan kehilangan independensinya. Auditor yang memiliki hubungan yang lama dengan perusahaan yang diaudit diyakini akan membawa konsekuensi ketergantungan tinggi atau ikatan ekonomik auditor yang kuat terhadap perusahaan. Semakin tinggi keterikatan auditor secara ekonomik, semakin tinggi kemungkinan auditor membiarkan perusahaan untuk memilih metoda akuntansi yang ekstrim. Jackson et al. (2009) manyatakan bahwa kualitas audit akan meningkat dengan adanya hubungan antara auditor dan klien. Variabel auditor tenure diukur dengan menghitung jumlah tahun sebuah KAP mengaudit laporan keuangan sebuah perusahaan secara berurutan (AL-Thuneibat et al., 2011). Penghitungan jumlah tahun tenure dilakukan ke belakang yaitu dimulai dari tahun 2014 dan terus ditelusuri sampai tahun dimana klien berpindah ke auditor lain.

\section{Kualitas Laba}

Kualitas laba adalah kemampuan informasi laba memberikan respon kepada pasar (Saiful dan Erliana, 2010). Kualitas laba menunjuk pada seberapa cepat dan tepat laba yang dilaporkan mengungkapkan laba fundamental. Laba dikatakan berkualitas jika tidak terdapat penyimpangan dari fakta sesungguhnya dalam proses memperolehnya serta secara teori tidak bertentangan dengan prinsip yang berlaku, sehingga keputusan yang diambil oleh pemakai tidak menimbulkan bias. Kuatnya reaksi pasar terhadap informasi laba juga mengindikasikan bahwa laba yang dilaporkan berkualitas. Semakin tinggi kualitas laba, maka semakin cepat dan tepat laba yang dilaporkan menyampaikan nilai sekarang dari dividen yang diharapkan. Kualitas laba berperan penting dalam mengendalikan portofolio investasi. Kualitas laba diukur dari nilai discretionary accrual (DACC), menggunakan pendekatan Jones Model (1991) yang telah dimodifikasi oleh Dechow dan Dichev (2002) dalam Boone et al., (2008). Model perhitungannya sebagai berikut:

DACCit $=\frac{T A C C i t}{T A i, t-1}-N D A C C i t$

DACCit = Discretionary Accruals perusahaan i periode $\mathrm{t}$.

TACCit $=$ Total accruals perusahaan i periode $\mathrm{t}$.

$T A i, t-1=$ Total Asset perusahaan i periode $\mathrm{t}-1$. 
NDACCit $=$ Nondicretionary accruals perusahaan i periode $\mathrm{t}$.

\section{Leverage}

Hadiningsih (2007) menjelaskan bahwa leverage merupakan kemampuan perusahaan untuk memenuhi kewajiban keuangannya baik jangka pendek maupun panjang jika saat perusahaan dilikuidasi. Leverage tinggi mengindikasikan perusahaan menggunakan leverage keuangan (financial leverage) yang tinggi sehingga akan meningkatkan rentabilitas modal saham dengan cepat. Perusahaan dengan financial leverage yang tinggi akan memiliki risiko yang semakin tinggi (Hanafi dan Halim, 2000).

Rasio leverage yang tinggi merupakan indikasi untuk membedakan perusahaan yang baik dan buruk, karena hanya perusahaan yang sehat dan kuat yang dapat berutang dengan menanggung risiko. Tingginya tingkat leverage akan meningkatkan kemungkinan kepailitan (kebangkrutan) dan selanjutnya akan meningkatkan risiko perusahaan (Saiful dan Erliana, 2010). Leverage diukur dengan membandingkan antara total utang terhadap total aset.

Leverage $=\frac{\text { Total Hutang }}{\text { Total Aset }}$

\section{Beta}

Beta menunjukkan hubungan antara saham dan pasarnya (saham secara keseluruhan). Beta juga berfungsi sebagai pengukur volatilitas return saham atau portofolio terhadap return pasar. Besarnya risiko suatu saham ditentukan oleh beta (Jogiyanto, 2003). Berdasarkan Capital Asset Pricing Model (CAPM), variasi tingkat return saham yang diharapkan akan terjadi dapat dijelaskan oleh beta (Pasaribu, 2009). Beta digunakan untuk mengukur kepekaan tingkat keuntungan suatu saham terhadap tingkat keuntungan suatu portofolio pasar. Besar kepekaan itulah yang ditunjukkan oleh beta(Hanafi dan Halim, 2000).

Beta menghubungkan kovarian dari sebuah aset dengan portofolio pasar dengan varian dari portofolio pasar. Nilai beta sangat mempengaruhi tingkat return yang diharapkan, semakin tinggi nilai beta dan return pasar maka akan semakin tinggi return yang disyaratkan oleh investor. Beta diperkirakan 
berkolerasi positif terhadap tingkat return yang diharapkan. Nilai Beta diperoleh dengan cara membagi kovarians return perusahaan dan return pasar (Cov Ri.RM) pada varians return pasar (Cov Ri.RM) dapat dihitung dengan rumus sebagai berikut (Hanafi dan Halim, 2000):

$\operatorname{Cov} R_{i t}, R_{M t}=\frac{\sum\left(R_{i t}-E\left(R_{i t}\right)\right)\left(R_{M t}-E\left(R_{M t}\right)\right)}{x}$

Rit $=$ Return saham perusahaan i pada periode $\mathrm{t}$.

$\mathrm{E}\left(\mathrm{R}_{\mathrm{it}}\right) \quad=$ Rata-rata return saham perusahaan pada periode $\mathrm{t}$.

$\mathrm{R}_{\mathrm{Mt}} \quad=$ Return pasar pada periode $\mathrm{t}$.

$\mathrm{E}\left(\mathrm{R}_{\mathrm{Mt}}\right) \quad=$ Rata-rata return saham perusahaan pada periode $\mathrm{t}$.

$x=$ Jumlah perusahaan yang menjadi sampel.

Nilai varians return saham (Var RM) diperoleh dengan rumus: $\operatorname{Var} R_{M t}=\Sigma\left(R_{M t}-E\left(R_{M t}\right)\right)^{2}$. Sehingga rumus untuk mencari beta, adalah:

$\beta=\frac{\operatorname{Cov} R_{\mathrm{it}} \cdot R_{M t}}{\operatorname{Var} R_{M t}}$

\section{Earning Per Share(EPS)}

Earning per share atau laba perlembar saham merupakan bentuk pemberian keuntungan yang diberikan kepada pemegang saham dari setiap lembar saham yang dimiliki. Hubungan laba yang diperoleh dengan investasi yang ditetapkan pemegang saham diamati secara cermat oleh komunitas keuangan. Investor mengharapkan manfaat dari investasinya dalam bentuk EPS. Sedangkan jumlah EPS yang akan didistribusikan kepada investor tergantung pada kebijakan perusahaan dalam hal pembayaran deviden (Mulyono, 2000). EPS diukur dengan menggunakan rumus sebagai berikut (Aloysius, 2004):

Earning Per Share $=\frac{\text { Laba Setelah Pajak }}{\text { Jumlah Saham Beredar }}$

\section{Analisis Data}

Penelitian ini menggunakan teknik analisis data regresi linier berganda untuk memperoleh gambaran yang menyeluruh mengenai pengaruh antara variabel auditor tenure, kualitas laba, leverage, beta, dan earning per share terhadap equity risk premium dengan menggunakan 
program SPSS versi 21 for Windows. Model regresi linier berganda yang dibuat adalah sebagai berikut:

$E R P_{t}=\alpha-b_{1}$ Tenure $_{t}-B_{2}$ KLaba $_{t}+$ b $_{3}$ Leverage $_{t}+{ }_{4}$ Beta $_{t}+{ }_{6}$ EPS $_{t}+e$

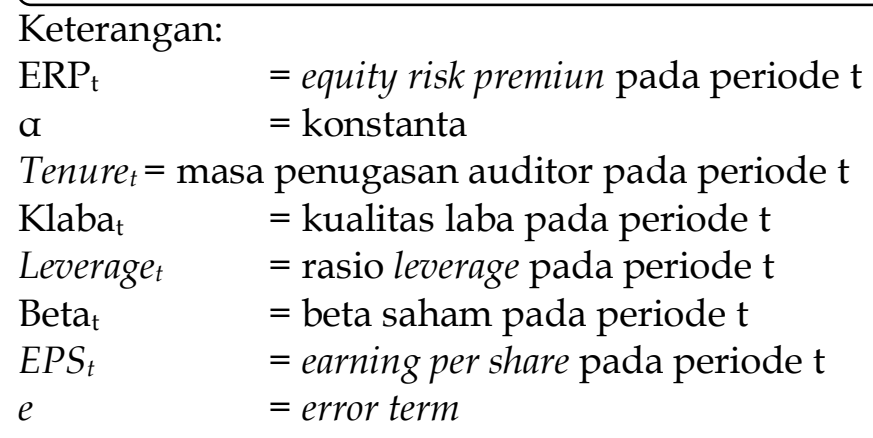

\section{B. Metode Penelitian}

Populasi dalam penelitian ini adalah seluruh perusahaan yang tercatat di Bursa Efek Indonesia (BEI). Sampel yang digunakan adalah industri perbankan yang terdaftar di BEI dari tahun 2010 sampai 2014. Pemilihan sampel yang dilakukan menggunakan teknik purposive sampling, yaitu pemilihan sampel berdasarkan kriteriasebagai berikut:

1. Telah menerbitkan dan mempublikasikan laporan keuangan auditan secara berturut-turut selama periode pengamatan,

2. Tidak delesting selama periode pengamatan,

3. Tidak mengalami kerugian secara berturut-turut selama periode pengamatan,

4. Memiliki data yang diperlukan selama periode pengamatan.

\section{Hasil dan Pembahasan}

Jumlah sampel yang memenuhi kriteria untuk dilakukan analisis data regresi linier sebanyak 23 industri perbankan dengan rincian sebagai berikut:

\section{Tabel 1. Proses Seleksi Sampel}

\begin{tabular}{|l|l|l|}
\hline No & Kriteria & Jmlh \\
\hline \hline 1 & $\begin{array}{l}\text { Industri perbankan yang terdaftar diBEI dari } \\
\text { tahun 2010-2014 }\end{array}$ & 41 \\
2 & Telah menerbitkan dan mempublikasikan & 30
\end{tabular}




\begin{tabular}{|l|l|l|} 
& $\begin{array}{l}\text { laporan keuangan auditan secara berturut-turut } \\
\text { dari tahun 2010-2014 }\end{array}$ & \\
3 & $\begin{array}{l}\text { Tidak delesting selama tahun 2010-2014 } \\
4\end{array}$ & $\begin{array}{l}\text { Tidak mengalami kerugian secara berturut-turut } \\
\text { selama tahun 2010-2014 }\end{array}$ \\
5 & $\begin{array}{l}\text { Memiliki data yang diperlukan selama tahun } \\
\text { 2010-2014 }\end{array}$ & 25 \\
6 & Data Outlier & 25 \\
\hline Jumlah Sampel & $\mathbf{2 3}$ \\
\hline
\end{tabular}

Hasil analisis uji asumsi klasik menunjukkan bahwa data telah terdistribusi normal (menggunakan One-Sample KolmogorovSmirnov Test dengan nilai Asymp. Sig. (2-tailed yaitu 0,660) dan tidak terjadi adanya pelanggaran asumsi (Multikolinieritas, Autokorelasi, dan Heteroskedastisitas). Selanjutnya dilakukan analisis data dengan regresi linier dan nampak hasil sebagai berikut:

Tabel 2. Hasil Analisis

\begin{tabular}{|c|c|c|c|}
\hline Variabel & $\bar{B}$ & Sig. & Keterangan \\
\hline Auditor Tenure & $-191,583$ & 0,029 & $\mathrm{H}_{1}$ Diterima \\
\hline Kualitas Laba & $-1,172$ & 0,004 & $\mathrm{H}_{2}$ Diterima \\
\hline Leverage & $-3076,410$ & 0,071 & $\mathrm{H}_{3}$ Ditolak \\
\hline Beta & $-85,997$ & 0,309 & $\mathrm{H}_{4}$ Ditolak \\
\hline Earning Per Share & 0,914 & 0,003 & $\mathrm{H}_{5}$ Diterima \\
\hline (Constant) & 2881,57 & & \\
\hline F Hitung & 6,173 & & \\
\hline Sig. F & 0,002 & & \\
\hline Adj. R. Square & 0,540 & & \\
\hline R. Square & 0,645 & & \\
\hline \multicolumn{3}{|c|}{ One-Sample Kolmogorov-Smirnov } & 0,660 \\
\hline
\end{tabular}

Hasil pengujian regresi linear berganda didapat persamaa berikut:

$E R P=2881,57-191,583$ Tenure - 1,172KLaba-3076,410Leverage85,997Beta $+0,914 E P S t+e$

Dari hasil uji ANOVA atau F test didapat nilai F hitung 6,173 dengan Sig. 0,002. Karena probabilitas lebih kecil dari 0,05 
maka model regresi dapat digunakan untuk memprediksi equity risk premium. Nilai adjusted $\mathrm{R}$ Square yaitu 0,54 (54\%), hal ini berarti bahwa $54 \%$ variabel equity risk premium dijelaskan oleh variasi dari ke lima variabel independen (audit tenure, kualitas laba, leverage, beta, dan earning per share). Sedangkan sisa nya $(100 \%-54 \%=46 \%)$ dijelaskan oleh variabel-variabel diluar model. Hasil analisis juga menunjukkan bahwa dari lima variabel independen yang diprediksi mempengaruhi equity risk premium, terdapat dua variabel yang terbukti tidak berpengaruh terhadap equity risk premium yaitu leverage dan beta.

\section{Pembahasan}

\section{a. Auditor tenure dan Equity Risk Premium}

Hasil pengujian menunjukkan bahwa variabel auditor tenure mempunyai nilai signifikan sebesar $0,029(<0,05)$, yang berarti variabel auditor tenure berpengaruh negatif signifikan terhadap equity risk premium. Hasil penelitian ini konsisten dengan penelitian yang dilakukan oleh Booneet al. (2008) yang menyatakan bahwa semakin panjang masa penugasan auditor akan menyebabkan integritas laporan keuangan yang menurun sehingga equity risk premium akan ikut menurun. Namun, hasil penelitian ini tidak mendukung penelitian Saiful dan Erliana (2010) yang menyatakan sebaliknya. Sejauh ini persepsi investor dan pandangan para akademisi menyatakan bahwa semakin lama penugasan seorang auditor, akan semakin tinggi integritas laporan akuntansi perusahaan, dan semakin rendah risiko informasinya yang menyebabkan equity risk premium menurun.

Kualitas yang rendah dari informasi keuangan perusahaan akan meningkatkan risiko informasi dan berakibat pada equity risk premium yang semakin tinggi. Tinggi rendahnya kualitas informasi keuangan perusahaan dapat dipengaruhi oleh auditor yang melakukan audit pada perusahaan tersebut. Kualitas audit bisa ditingkatkan jika auditor diganti secara periodik (Febrianto, 2008). Selain itu Mansi et al. (2004) menjelaskan bahwa tenure (masa penugasan audit) yang semakin lama akan mengurangi konservatisme dalam pelaporan keuangan, semakin lama tenure akan mengakibatkan semakin kecilnya kualitas auditor. Semakin 
panjang penugasan audit, akan mengakibatkan ketergantungan auditor pada klien yang menyebabkan auditor kehilangan independensinya, hal itu akan mengakibatkan besarnya kemungkinan kualitas laporan informasi keuangan menjadi rendah dan berdampak pada tinggi rendahnya equity risk premium.

\section{b. Kualitas Laba dan Equity Risk Premium}

Hasil pengujian menunjukkan bahwa variabel kualitas laba mempunyai nilai signifikan sebesar 0,004 $(<0,05)$, yang berarti variabel kualitas laba berpengaruh negatif signifikan terhadap equity risk premium. Hal ini dikarenakan kualitas laba yang diukur dari discretionary accrual merupakan komponen akrual yang memungkinkan manajer melakukan intervensi dalam memanipulasi laba perusahaan. Aktivitas ini menyebabkan perusahaan tidak menampilkan laba yang sebenarnya, sehingga investor yang melihat informasi perusahaan melalui laporan keuangan tidak ingin melakukan investasi pada perusahaan yang melakukan manipulasi laba tersebut. Hasil penelitian ini konsisten dengan Booneet al. (2008) yang menyatakan bahwa semakin tinggi akrual menunjukkan perusahaan berkualitas rendah sehingga menurunkan equity risk premium perusahaan.

\section{c. Leverage dan Equity Risk Premium}

Hasil pengujian menunjukkan bahwa variabel leverage mempunyai nilai signifikan sebesar $0,071(>0,05)$, yang berarti variabel leverage tidak berpengaruh terhadap equity risk premium. Hal ini dikarenakan leverage yang diproksikan dengan Debt to Total Aset, menunjukkan berapa bagian dari keseluruhan kebutuhan dana yang dibelanjai dengan hutang atau berapa bagian aset yang digunakan untuk menjamin hutang. Karena hutang dijaminkan oleh total aset maka tidak memberikan pengaruh terhadap risiko dalam melakukan investasi pada saham. Pada laporan keuangan perbankan yang menjadi sampel dalam penelitian ini menunjukkan bahwa nilai leverage perusahaan perbankan, secara keseluruhan nilainya kurang dari 1 (satu) yang artinya jika rasio leverage kurang dari satu maka semakin baik tingkat leverage perusahaan tersebut dalam melunasi hutang-hutangnya. Sehingga tidak ada risiko 
akan kebangkrutan perusahaan. Tidak adanya risiko atas kemampuan perusahaan membayar hutang secara otomatis akan mengurangi tambahan return atau equity risk premium. Hasil penelitian ini konsisten dengan penelitian Kurniawan (2013) namun tidak sependapat dengan penelitian Bhandari (1988) yang menyatakan leverage memiliki hubungan yang positif terhadap tingkat return yang diharapkan.

\section{d. Beta dan Equity Risk Premium}

Hasil pengujian menunjukkan bahwa variabel beta mempunyai nilai signifikan sebesar 0,309 $(>0,05)$, yang berarti variabel beta tidak berpengaruh terhadap equity risk premium. Besarnya risiko suatu saham ditentukan oleh beta (Jogiyanto, 2003). Investor cenderung tidak tertarik untuk berinvestasi pada sektor perbankan dibandingkan industri sektor konsumtif. Hal ini karena industri perbankan sudah dikuasai atau dimonopoli oleh bank-bank besar, seperti Bank Mandiri, Bank BCA, Bank BRI dan Bank BNI (Erlangga, 2015). Sehingga besarnya risiko dalam suatu saham (dalam hal ini beta) tidak berpengaruh terhadap equity risk premium karena jarang ada investor yang ingin berinvestasi pada perusahaan perbankan sehingga mengurangi risiko investasi Hasil ini konsisten dengan penelitian yang dilakukan oleh Fama dan French, (1992) bahwa beta memiliki sedikit kemampuan untuk menjelaskan return yang diharapkan pada saham, sehingga tidak terjadi dampak dalam perolehan tambahan return yang diharapkan oleh investor. Namun, hasil penelitian ini tidak mendukung hasil penelitian yang dilakukan oleh Boone etal. (2008)yang menemukan bahwa beta berpengaruh positif terhadap equity risk premium.

\section{e. Earning Per Share (EPS) dan Equity Risk Premium}

Hasil pengujian menunjukkan bahwa variabel EPS mempunyai nilai signifikan sebesar 0,003 $(<0,05)$, yang berarti variabel EPS berpengaruh positif signifikan terhadap equity risk premium. Hal ini disebabkan karena dari gambaran EPS investor akan berekspektasi manfaat dari investasinya dalam bentuk laba dari per lembar sahamnya. Investor akan mengharapkan manfaat dari investasinya dalam bentuk laba per lembar saham. Sedangkan jumlah EPS yang akan 
didistribusikan kepada investor tergantung pada kebijakan perusahaan dalam hal pembayaran deviden. Hasil penelitian ini mendukung hasil penelitian Booneet al. (2008) yang menyatakan bahwa earning per share berpengaruh positif signifikan terhadap equity risk premium. Akan tetapi tidak mendukung penelitian Al-Hayat (2014) yang menyatakan sebaliknya.

\section{Simpulan \& Saran}

Berdasar hasil penelitian dapat ditarik kesimpulan bahwa faktor-faktor yang mempengaruhi equity risk premium pada industri perbankan yang terdaftar di BEI adalah auditor tenure, kualitas laba, dan earning per share. Sedangkan untuk leverage dan beta tidak berpengaruh terhadap equity risk premium dalam kurun waktu penelitian tahun 2010-2014 pada Industri Perbankan. Mengingat sampel perusahaan dalam penelitian ini hanya industri perbankan, hal ini berdampak terhadap hasil penelitian yang tidak dapat digeneralisasi ke industri yang lain. Dengan demikian, penelitian selanjutnya agar memperluas sampel perusahaan dari jenis perusahaan yang berbeda sehingga dapat dilihat bagaimana variabelvariabel independen dalam penelitian ini mempengaruhi variabel dependennya untuk jenis perusahaan yang berbeda. Pengujian koefisien determinasi menunjukkan bahwa masih ada sekitar $46 \%$ variabel lain yang mempengaruhi equity risk premium. Diharapakan penelitian selanjutnya dapat menggali lebih dalam terhadap faktor apa saja yang dapat mempengaruhi serta menambah rentang waktu penelitian, sehingga memberikan hasil yang lebih akurat. 
Yunus Harjito dan Dian Indriana Hapsari

\section{Daftar Pustaka}

Al-Hayat, W. 2014. Pengaruh Rasio Keuangan Terhadap Return Saham (Studi Empiris Pada Perusahaan Sektor Pertambangan yang Terdaftar di Bursa Efek Indonesia Periode 2008-2013). Skripsi. Surakarta: Universitas Muhammadiyah Surakarta.

Aloysius, H.S. 2004. Analisa Pengaruh Faktor Fundamental Perusahaan Terhadap Total Return Di Bursa Efek Jakarta.Tesis. Semarang: Magister Manajemen Universitas Diponegoro.

Al-Thuneibat, A.A., Al Issa, R.T.I dan Baker, R.A.A. 2011. Do Audit Tenure and Firm Size Contribute to Audit Quality.Managerial Auditing Journal.

Annin, M. danFalaschetti D. 1998. Equity Risk Premium Article. IL: Ibbotson Associates.

Bhandari, L. C. 1988. Debt/Equity Ratio and Expected Commond Stock Returns: Empirical Evidence. Journal Of Finance.

Boone, J. P., Khurana, Inder K. dan Raman, K. K. 2008. Audit Firm Tenure and The Equity Risk Premium.Journal of Accounting Auditing and Finance. http:/ / ssrn.com/abstract=940401.(27 November 2015)

Chen., Zhang., Ganesh. 2006. Financial Distress Prediction in China.Review dari Pasific Basic Financial Markets and Policies, Volume 9, Iss 2, Halaman 317.

Damodaran, Aswath. 2009. Measuring Country Risk. Working Paper, ssrn.com. Tersediadi:pages.stern.nyu.edu/adamodar/pdfiles/papers/ERPfull.pdf.

Diaz, M. 2009. Analisa Reaksi Pasar Terhadap Pengumuman Pergantian Kantor Akuntan Publik (Studi Pada Perusahaan Publik Di Indonesia). Palembang: Simposium Nasional Akuntansi 12. Palembang. 
Erlangga, Agung. 2015. Pengaruh Sistem Pengendalian Manajemen dan Pengendalian Internal terhadap Kinerja Karyawan (studi kasus pada PT.INTI). Bandung: Universitas Kristen Maranatha.

Fama, E. F. dan French, Kenneth R. 1992. The Cross Section of Expected Returns.Journal of Finance. Volume 47 (2).

Febrianto, R. 2008. Pergantian Auditor dan Kantor Akuntan Publik. Tersedia di: www.google.co.id di Rahmat on Accounting.

Francis, J., LaFond, R., Olsson, P., dan Schipper, K. 2004. Cost of Capital and Earnings Attributes. The Accounting Review 74 (4): 967.

Gebhart, W., Lee, C., dan Swaminathan, B. 2000. Toward and Implied Cost of Capital.Journal of Accounting Research Volume 39 (1): 135-176.

Ghozali, I. 2013. Aplikasi Analisis Multivariate Dengan Program IBM SPSS 21. Edisi Ketujuh. Semarang: Badan Penerbit Universitas Diponegoro.

Hadiningsih, M. 2007. Analisis Dampak Jangka Panjang Merger dan Akuisisi terhadap Kinerja Keuangan Perusahaan Pengakuisisi dan Perusahaan Diakuisisi di Bursa Efek Jakarta (BEJ). Yogyakarta: Fakultas Ekonomi. Universitas Islam Indonesia.

Halim, A. 2005. Analisis Investasi. Edisi Kedua. Jakarta: Salemba Empat.

Hanafi, M., M dan Halim, A. 2000. Analisis Laporan Keuangan. Edisi Revisi: Yogyakarta. UPP AMP YKPN.

http://www.bi.go.id/id/moneter/bi-rate/data/Default.aspx diakses pada tanggal 18 Oktober 2015. 
http:/ / www.idx.co.id/idid/beranda/perusahaantercatat/lapo rankeuangandantahunan.aspx diakses pada tanggal 24 November 2015.

http:/ / www.investopedia.com/terms/e/equityriskpremium.a sp diakses pada tanggal 8 Oktober 2015.

Husnan, Suad. 2003. Manajemen Keuangan Teori dan Penerapan (keputusan Jangka Pendek), Edisi keempat.Yogyakarta: BPFE

Jackson et al. (2009). Managerial Accounting: A Focus on Ethical Decision Making, $5^{\text {th }}$ Edition, South Western, USA: Cengage Learning.

Jensen, C. Michael and Meckling H. William. 1976. Theory of the Firm: Managerial Behavior, Agency Costs and Ownership Structure. Journal of Financial Economics.

Jogiyanto. 2003. Teori Portofolio dan Analisis Investasi. Edisi Ketiga. Yogyakarta: BPFE UGM.

Kurniawan, U. 2013. Analisis Faktor-Faktor yang Mempengaruhi Equity Risk Premium Perusahaan di Indonesia. Skripsi. Lampung: Fakultas Ekonomi Universitas Lampung.

Leuz, C. dan Verrechia, R. 2005. Firms Capital Allocation Choices, Information Quality, and The Cost of Capital. Working Paper. Univesity of Pennsylvania.

Mansi, S., D. Miller, and W. Maxwell, 2004. Does auditor quality and tenure matter to investors: Evidence from the bond market.Journal of Accounting Research 42, 755-793.

Markowitz, Harry. 1952. Portofolio Selection. The Journal of Finance.Vol.7. American Finance Association.

Martin, J. R., Fuentes, San dan Lilo, S. Z. 2003. The Equity Risk Premium in Emerging Market: The Case of Chile. Tersedia di: http://www.cemla.org/pdf/redix/RED-IX-ch.pdf. (27 November 2015) 
Mulyono, Agus. 2000. Manajemen Bisnis Logistik, Yogyakarta: BPFE

Pasaribu, Rowlan, Bismark, Fernando. 2009. Model Fama dan French sebagai Pembentukan Portofolio Saham di Indonesia. Jurnal Akuntansi dan Bisnis 9 (1) : 1-12.

Rahmawati, Yacob S., Nurul Q. 2006. Pengaruh Asimetri Informasi terhadap Praktek Manajemen Laba pada Perusahaan Perbankan Publik yang terdaftar di Bursa Efek Jakarta. Simposium Nasional Akuntansi 9. Padang.

Saiful dan Erliana, Uvi Elin. 2010. Equity Risk Premium Perusahaan yang Terdaftar di Bursa Efek Indonesia dan Faktor-Faktor yang Mempengaruhinya.Purwokerto. Makalah Disajikan Pada Simposium Nasional Akuntansi 13. Purwokerto

Situmorang, E. J. 2015. Pengaruh Kualitas Laba, EPS, Ukuran Perusahaan, Leverage, dan Beta Terhadap Equity Risk Premium (Pada Perusahaan Properti dan Real Estate yang Terdaftar di Bursa Efek Indonesia Tahun 2011-2014). Skripsi. Riau: Jurusan Akuntansi Fakultas Ekonomi Univesritas Maritim Raja Ali Haji.

Yee, K. K. 2006. Earning Quality and The Equity Risk Premium: A Bechmark Model. Tersedia di: http:// papers.ssrn.com (27 Nvember 2015) 